\title{
ON THE EFFECTS OF THE CLUB ROOT FUNGUS (PLASMODIO- PHORA BRASSICAE WORON) AND WINTER FROST ON THE OVERWINTERING OF WINTER TURNIP RAPE
}

\author{
Onni Pohjakallio, Anna Marja Halkilahti and Simo Antila \\ Department of Plant Pathology, University of Helsinki
}

Received April 10, 1959

According to Haavisto $(3,4)$, Valle (11), Breitenstein (2), Jamalainen $(6,7)$, and PoHJAKallio \& SALONEN $(10)$ the overwintering of winter turnip rape in Finland is threatened by low temperature fungi, winter frost, soil frost, ice scorch and surface water; in addition, the larvae of the cabbage root fly (Hylemyia brassicae) can reduce its winterhardiness. In field experiments carried out at Muddusniemi experimental Farm $\left(69^{\circ} 5^{\prime} \mathrm{N}\right)$ in Lapland (10) the stands of winter turnip rape were infected by the low temperature parasitic fungi Sclerotinia sp., Typhula sp., and Fusarium sp. However, the overwintering of the stands appeared to be most threatened by spring frosts, although these were not severe enough to damage either winter rye or most of the grasses. The overwintering of the latter was adversely affected chiefly by the low temperature parasitic fungi, and it was possible to control these fungi with PCNB preparations, although PCNB treatment had no effect on the overwintering of the winter turnip rape. On the other hand, in experiments carried out in South Finland (5), PCNB treatment had a very benificial effect on the overwintering of winter turnip rape.

In the following paper special attention has been paid to the effects of winter frosts, and of the Plasmodiophora brassicae Woron infection upon the overwintering of winter turnip rape. The field experiments have been carried out at Viik Experimental Farm in South Finland $\left(60^{\circ} 10^{\prime} \mathrm{N}\right)$.

\section{Methods}

In 1951, 1952, 1953, and 1954 sowing-time trials of winter turnip rape were started in a field contaminated with the club root fungus (Plasmodiophora brassicae). The size of the experimental plots was $5 \mathrm{~m}^{2}$ in 1951 and $2 \mathrm{~m}^{2}$ from 1952 to 1954; the number of replicates was 4; the distance between seed rows was $50 \mathrm{~cm}$ in the 
first experiment, $25 \mathrm{~cm}$ in the others; the seed rate was $5 \mathrm{~kg}$ per hectare. In two of the experiments the ratio of club root diseased plants was studied in the autumn (Table 1); the number of plants examined was 2770 in 1950 and 1735 in 1952 . Every spring the proportion of diseased plants among the overwintered plants was determined.

Table 1. Club root infection and overwintering of winter turnip rape stands sown at different dates.

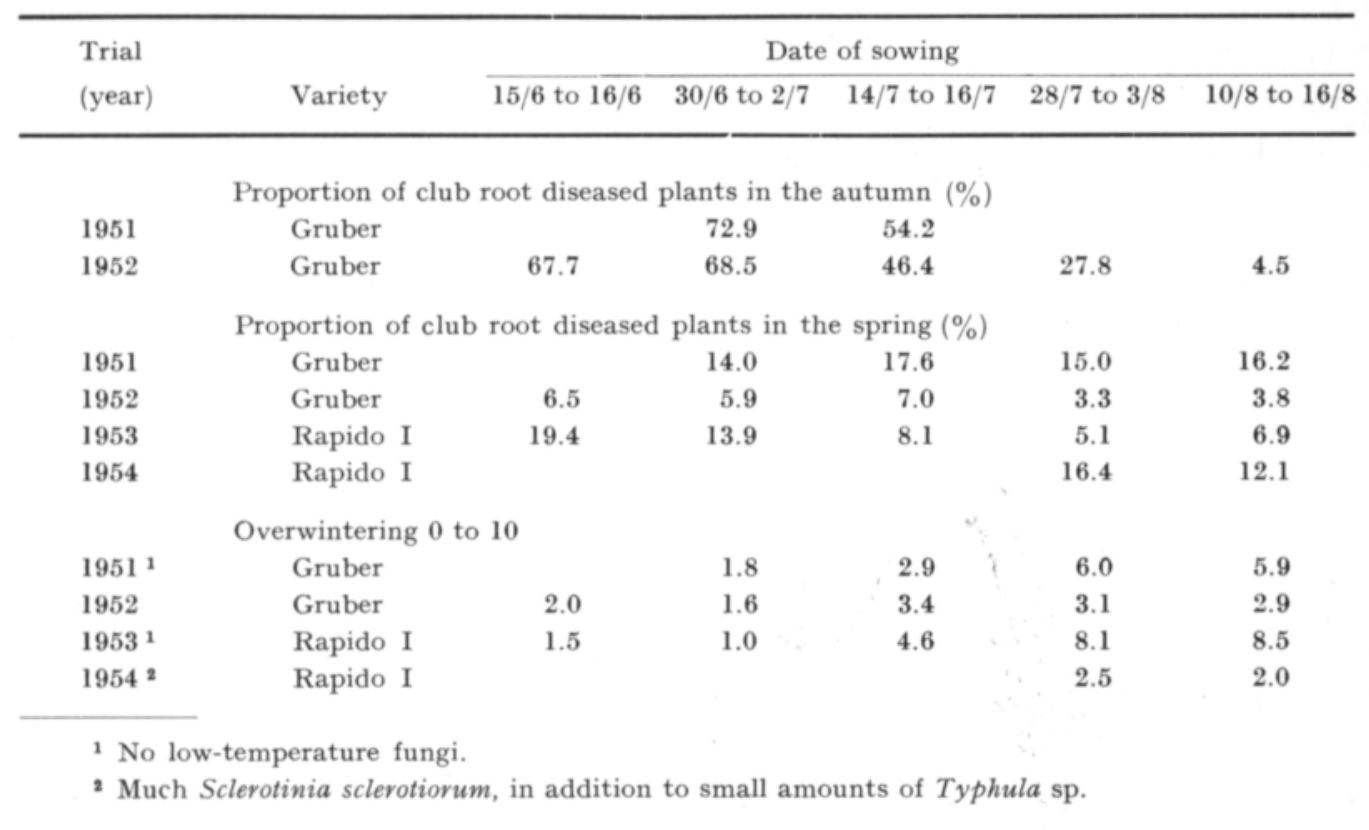

The overwintering of the plants was estimated on a scale of 0 to 10 , of 0 signifying that all the plants were dead, 5 that half the plants were dead, and 10 that all the plants were living. In addition, the occurrence of low-temperature fungi was noted.

In spring 1956, a study was made of the overwintering of winter turnip rape and the condition of the overwintered plants growing in 10 different areas of a field not contaminated by club root fungus. One of the areas (area 10) was covered with a thick layer of snow during the entire winter; the other areas were almost without snow. No ice cover was observed on the surface of the field. Areas 1 and 7 were rises, areas 3 and 6 depressions in the ground. Area 2 was the side of a rise, and areas $4,5,8$, and 9 were level parts of the field.

Because the tap root of many plants was injured in such a way as to appear frost-damaged, the resistance to cold of different parts of the winter turnip rape plant was studied. The plants examined were grown outdoors and tested in the following way: The soil was washed out from the roots with cold water; the plants were placed for periods of $1 / 2,1,2,3,4,6,8$, or 24 hours (Dec. 19, 1958 for periods of $8,24,48,72$ or 94 hours) in a thermostat room at $-15^{\circ} \mathrm{C}$, and then kept a) in water, or b) without water in another thermostat room at 4 to $7^{\circ} \mathrm{C}$ (12 to 36 hours). 
The control plants were kept the whole time at 4 to $7^{\circ} \mathrm{C}$. All the plants were then simultaneously moved to a laboratory $\left(+20^{\circ} \mathrm{C}\right)$, where they were tested after 2 hours; the results were checked after 26 hours.

The freezing injuries occurring in the plants treated at $-15^{\circ} \mathrm{C}$ were tested a) by estimating the flaccidity and withering of different sections of the plant as well as b) by using the tetrazolium test (cf. 9). The flaccidity and the withering of the foliage was estimated on a scale of 0 to 10,0 signifying that the whole leaf was dead, 5 that the petiole was living, and 10 that the entire leaf was living. The withering of the tap root (Fig. 4) was examined visually, as well as by feeling the root with the fingers; the result was estimated on a scale of 0 to 10 .

In the tetrazolium test (cf. 1, 9), the regions of the plant to be examined (the base of the plant and the tap root $3 \mathrm{~cm}$ beneath the base) were immersed in a solution consisting of $1 \mathrm{~g}$ of $2,3,5,-$ triphenyltetrazolium chloride in $100 \mathrm{~g}$ of water, and were kept in the dark at approx. $20^{\circ} \mathrm{C}$. After one hour the results were estimated on a scale of 0 to 10,10 signifying that the entire tissue was red-coloured (living), and 0 that no red colour was present (Fig. 1).
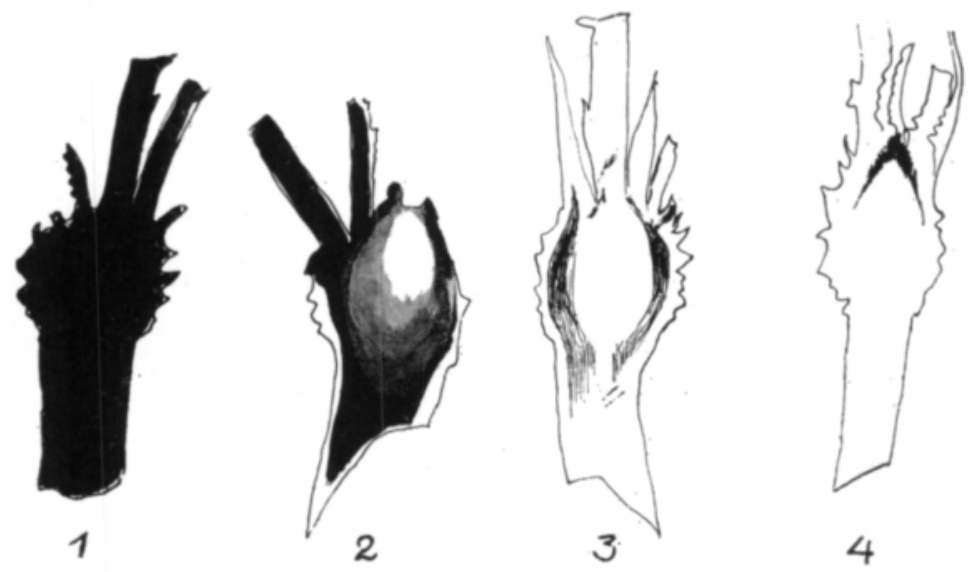

Fig. 1. Estimation of the vitality of the base of the winter turnip rape on a scale of 0 to 10 :

1: wholly coloured (wholly living) $=10$

2: $8 / 10$ of the base coloured $\quad=8$

$3: 3 / 10 \quad-\quad=3$

4: $2 / 10 \quad-\rightarrow-\quad=2$

\section{Experimental results}

In the sowing-time trials the proportion of club root diseased winter turnip rape plants appeared to be considerably higher before than after the overwintering (Table 1); this means that a higher proportion of the diseased than of the healthy plants has died during the winter. Consequently, the club root disease had reduced the winterhardiness of the plants. In the late-seeded stands the ratio of diseased plants was relatively low, and correspondingly, their overwintering was adequate during the winters in which no low temperature fungi were to be seen. 
Table 2. Overwintering of Gruber winter turnip rape and occurrence of damaged roots in the living plants, May 31, 1956.

\begin{tabular}{lccc}
\multicolumn{1}{c}{ Area ${ }^{1}$} & $\begin{array}{c}\text { No. of plants } \\
\text { examined }\end{array}$ & $\begin{array}{c}\text { Overwintering } \\
0 \text { to } 10\end{array}$ & $\begin{array}{c}\text { Proportion of reco- } \\
\text { vered plants with } \\
\text { injured tap root (\%) }\end{array}$ \\
\hline 1 and 7:rise in the ground & 161 & 2.5 & 6.5 \\
2:side of a rise in the ground & 86 & 5.0 & 4.7 \\
$4,5,8$, and 9: flat areas & 397 & 4.4 & 6.0 \\
3, 6: depression in the ground & 113 & 2.8 & 5.7 \\
10: abundant snow in winter & 211 & 8.8 & 0.0 \\
& & & 8.4 \\
$1,3,6,7$, and 8 & 297 & $<-6$ & 3.2 \\
2,6 , and 9 & 239 & $>6$ & 0.7 \\
4 and 10 & 432 & &
\end{tabular}

1 Areas 1 to 9 with almost no snow.

During the winter of $1955-1956$ in another field not contaminated by club root fungus, the winter turnip rape overwintered best in areas where there was abundant snow (Table 2). In areas with almost no snow the stand had thinned out considerably. Because no low temperature fungus infection of the plants or accumulation of surface water was observed, it seemed probable that the damage

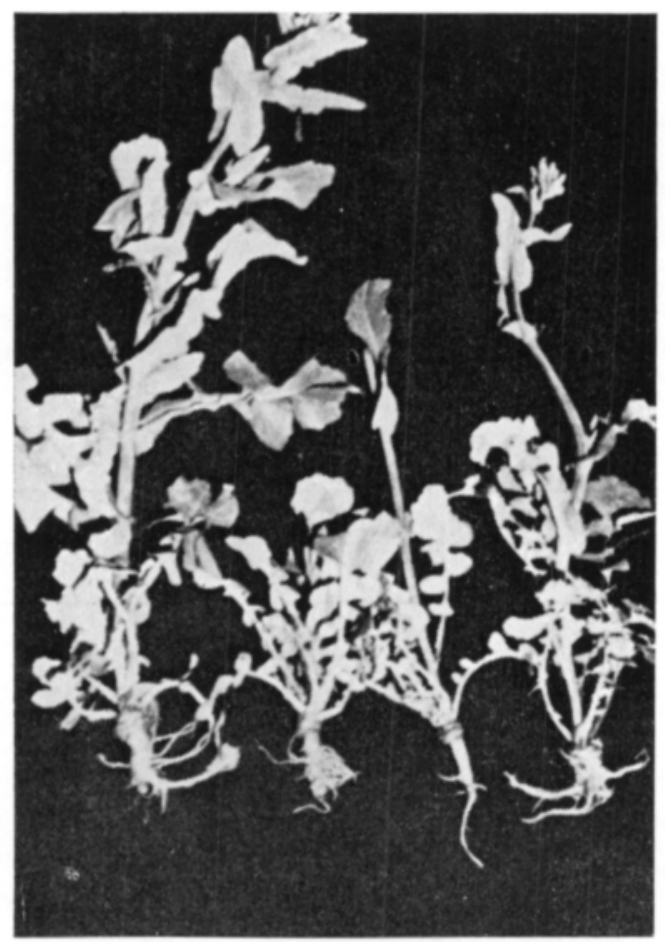

Fig. 2. Winter turnip rape plants, the tap root of which has been frozen during the winter. 
was caused by frost. This opinion was supported by the fact that the stand was damaged most severely upon rises of the ground. Also the layer of ice needles in the surface of the soil causing disruption (cf. 8) had not broken the roots of the plants; the tap root of the plants which had died during the winter was withered but not broken.

During an examination of plants which had survived the winter, it was observed that many of them, when pulled up, easily came loose from the soil. The lower part of the tap root, beginning 2 to $3 \mathrm{~cm}$ beneath the base of the plant, was dead; the plant, however, recovered (Fig. 2). Most of the plants with damaged roots were found in stands growing upon rises in the ground; in areas covered with a thick layer of snow during the whole winter this phenomenon was not seen at all (Table 2). Besides, the proportion of injured plants appeared to be higher where the overwintering of the stand was poorer. Therefore it seemed presumable that the winter frost, which was apparently the main cause of the death of the plants, had in many cases injured only the lower part of the tap root, whereas the plant itself was able to recover in the spring.

Table 3. Cold resistance of different parts of a Rapido I winter turnip rape plant Nov. 11, 1958

\begin{tabular}{ccccc}
\hline Duration of & & \multicolumn{3}{c}{ Vitality (0 to 10) } \\
the treatment $\begin{array}{c}\text { No. of the } \\
\text { plants } \\
\text { at }-15^{\circ} \mathrm{C} \\
\text { (hours) }\end{array}$ & \begin{tabular}{c} 
plamined \\
\cline { 3 - 5 }
\end{tabular} & Tap root & Leaves \\
\cline { 3 - 6 }
\end{tabular}

Estimated after withering.

$\begin{array}{crrrrrr}0 & 17 & 10.0 & 10.0 & 10.0 & 10.0 & 10.0 \\ 1 / 2 & 20 & 1.4 & 9.4 & 5.6 & 8.7 & 10.0 \\ 1 & 15 & 0.0 & 1.4 & 4.9 & 8.3 & 10.0 \\ 2 & 17 & 0.0 & 0.7 & 3.7 & 5.7 & 10.0 \\ 3 & 18 & 0.0 & 0.0 & 0.8 & 2.3 & 8.2 \\ 4 & 17 & 0.0 & 0.0 & 0.0 & 0.0 & 4.4 \\ 6 & 18 & 0.0 & 0.0 & 0.0 & 0.0 & 8.2 \\ 8 & 19 & 0.0 & 0.0 & 0.0 & 0.0 & 6.0 \\ 24 & 18 & 0.0 & 0.0 & 0.0 & 0.0 & 2.8\end{array}$

Estimated from the tetrazolium test.

\begin{tabular}{cccccc}
\hline & \multicolumn{2}{c}{ Tap root $^{1}$} & \multicolumn{2}{c}{ Base of plant } \\
\cline { 3 - 6 } & & $\varnothing<1 \mathrm{~cm}$ & $\emptyset>1 \mathrm{~cm}$ & $\emptyset<1 \mathrm{~cm}$ & $\emptyset>1 \mathrm{~cm}$ \\
\hline 0 & 4 & 10 & 10 & 10 & 10 \\
$1 / 2$ & 4 & 10 & 10 & 10 & 10 \\
1 & 4 & 0 & 8 & 7 & 8 \\
2 & 4 & 0 & 7 & 7 & 8 \\
3 & 4 & 0 & 0 & 3 & 3 \\
4 & 4 & 0 & 0 & 0 & 2 \\
6 & 4 & 0 & 0 & 0 & 3 \\
8 & 4 & 0 & 0 & 0 & 1
\end{tabular}

$13 \mathrm{~cm}$ below the base of the plant. 
Table 4. Cold resistance of different parts of a Rapido I winter turnip rape plant Dec. 19, 1958. Each treatment 10 plants.

\begin{tabular}{|c|c|c|c|}
\hline \multirow{3}{*}{$\begin{array}{c}\text { Duration of } \\
\text { the treatment } \\
\text { at }-15^{\circ} \mathrm{C} \\
\text { (hours) }\end{array}$} & \multicolumn{3}{|c|}{ Vitaly $(0$ to 10$)$} \\
\hline & \multirow{2}{*}{$\begin{array}{l}\text { Estimated } \\
\text { after wither- } \\
\text { ing of inner- } \\
\text { most leaves }\end{array}$} & \multicolumn{2}{|c|}{$\begin{array}{c}\text { Estimated after the tetrazolium test } \\
\text { Tap root }(\emptyset>1 \mathrm{~cm})\end{array}$} \\
\hline & & $\begin{array}{l}3 \mathrm{~cm} \text { below the } \\
\text { base of the plant }\end{array}$ & Base of plant \\
\hline 0 & 10.0 & 10.0 & 10.0 \\
\hline 8 & 9.1 & 6.0 & 10.0 \\
\hline 72 & 8.5 & 7.5 & 10.0 \\
\hline 94 & 7.6 & 9.0 & 10.0 \\
\hline
\end{tabular}

\begin{tabular}{|c|c|c|c|c|}
\hline \multirow{3}{*}{$\begin{array}{c}\text { Duration of } \\
\text { the treatment } \\
\text { at }-15^{\circ} \mathrm{C} \\
\text { (hours) }\end{array}$} & \multirow{3}{*}{$\begin{array}{l}\text { Estimated after } \\
\text { withering of } \\
\text { innermost leaves }\end{array}$} & \multicolumn{3}{|c|}{ Estimated after the tetrazolium test } \\
\hline & & Tap $\mathrm{r}$ & & \multirow[b]{2}{*}{ Base of plant } \\
\hline & & $\begin{array}{l}3 \mathrm{~cm} \text { below the } \\
\text { base of the plant } \\
(\varnothing 1 \mathrm{~cm})\end{array}$ & $\begin{array}{l}\text { lower } \\
\text { half }\end{array}$ & \\
\hline
\end{tabular}

$\begin{array}{rrrcr}0 & 10.0 & 10.0 & 10.0 & 10.0 \\ 1 / 2 & 10.0 & 9.8 & 9.0 & 10.0 \\ 1 & 10.0 & 9.5 & 0 & 10.0 \\ 2 & 10.0 & 5.2 & 0 & 8.0 \\ 3 & 10.0 & 5.0 & 0 & 8.0 \\ 4 & 10.0 & 4.5 & 0 & 7.0 \\ 6 & 10.0 & 4.0 & 0 & 8.0 \\ 8 & 10.0 & 5.0 & 0 & 8.0 \\ 24 & 8.0 & 0.0 & 0 & 2.0\end{array}$

During periods of frost the temperature must be lower above the soil surface than below it. Consequently the injury to the tap root of a recovered plant can only be considered to be caused by frost if the root proves to be perceptibly more sensitive to damage by freezing than the sections of the plant above it.

In the experiments carried out in the thermostat room $\left(-15^{\circ} \mathrm{C}\right)$ considerable differences in the frost resistance of different regions of the plant were observed. The smallest, innermost leaves in the rosette and the base of the plant appeared to be the most resistant, and the root the most sensitive part of the winter turnip rape plant (Tables 3 to 5, Fig. 3). The resistance to cold of the winter turnip rape appeared to be higher on Dec. 19 than on Nov. 11 or March 23. In addition, there were noticeable differences in the frost resistance of different plants; the larger plants with a thick tap root appeared to be the most frost resistant. Both Nov. 11, and Dec. 19, 1958 the colour of the innermost leaves of the plants was green, March 23 it was yellow. The yellow coloured leaves in some of the plants were infected by a Typhula sp. 


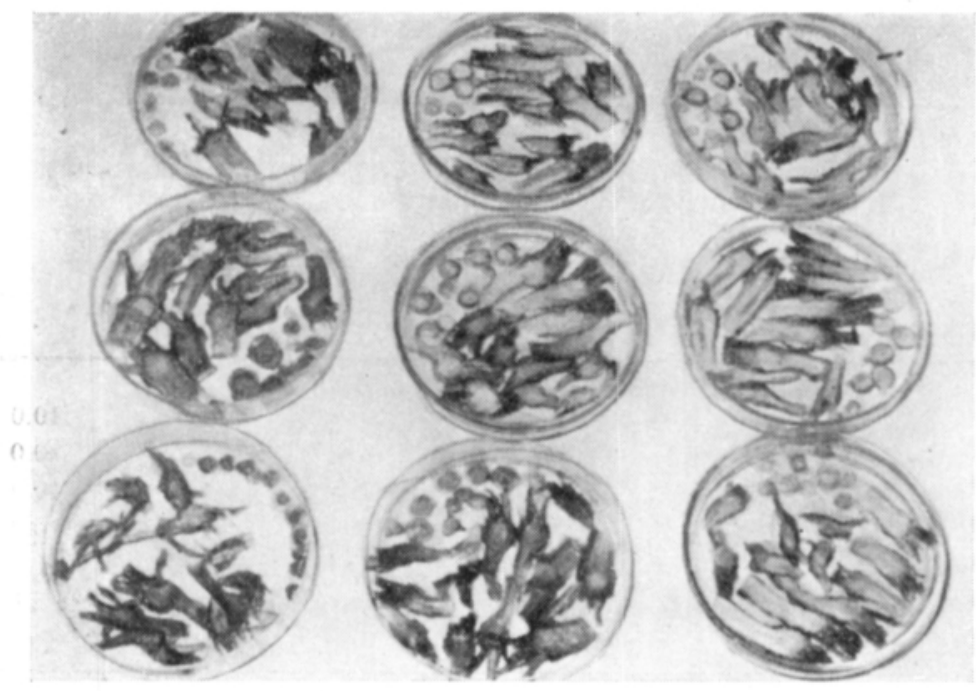

Fig. 3. Vertical sections of the base and transverse sections of the tap root $(3 \mathrm{~cm}$ belcw the base) of winter turnip rape. Results of the tetrazolium test after treatments at $-15^{\circ} \mathrm{C}$. Duration of treatment (hours):

$\begin{array}{rrr}0 & 1 / 2 & 1 \\ 2 & 3 & 4 \\ 6 & 8 & 24\end{array}$

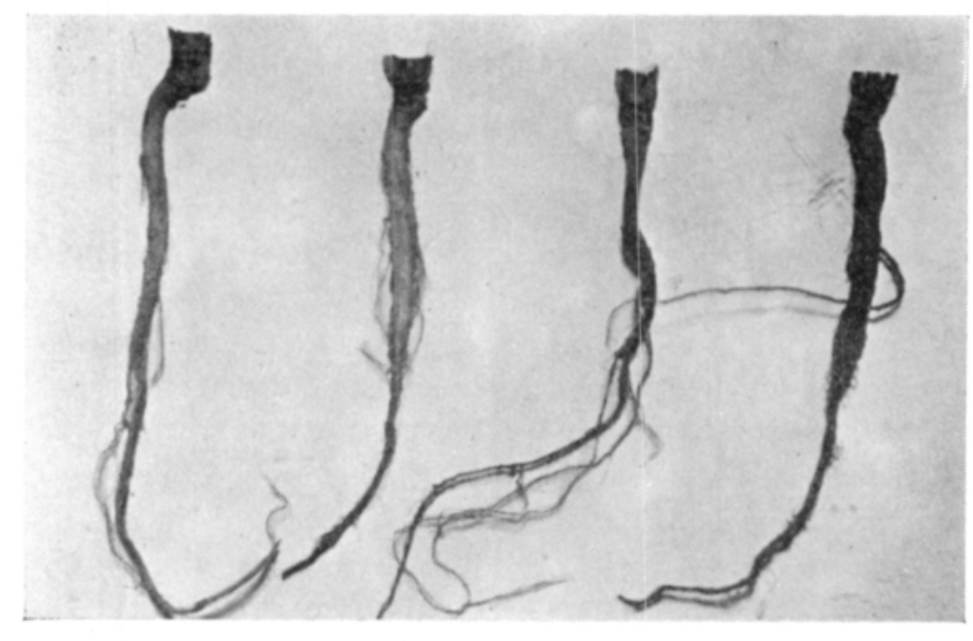
0 hours $1 / 2$ hours
1 hours
2 hours

Fig. 4. Tap roots of winter turnip rape. The plants were treated at $-15^{\circ} \mathrm{C}$ for times of (from left) $0,1 / 2,1$ and 2 hours; after 2 days the dead sections of the tap root have become dark coloured. 
1 Plasmodiophora brassiceae infection perceptibly reduced the winterhardiness of winter turnip rape.

2. The freezing of the plants, even when they were not club root diseased, appeared to be a general phenomenon in stands not covered by a layer of snow during the winter.

3. The root system appeared to be the most frost-sensitive part of the plant.

4. In many cases the plants were able to recover in the spring in spite of the freezing of the tap root during the winter.

REFERENCES :

(1) AHLBERG, ERKKI 1954. Korsiviljojen itävyyden pikamääritys 2, 3, 5 -trifenyltetrazoliumkloridilla (Die Ermittlung der Keimfähigkeit der Getreidefrüchte mit Tetrazolium-schnellmethode). J. Agric. Sci. Finl. 26: 96-112.

(2) Breitenstein, W. 1955. Kokemuksia syysrypsin talvehtimisesta ruotsinkielisellä Uudellamaalla. Kasviöljy 1955, 3: 11-12.

(3) Hanvisto, M. 1954. Syysöljykasvien talvituhosienistä. Koetoim. ja käyt. 11: 11.

(4) - 1956. Typhula betae Rostr. in winter turnip rape. J. Agric. Sci. Finl. 28:

(5) Haavisto, M., Jamalainen, E. A. \& Ylimäki, Aarre 1956. Observations on the effect of pentachlornitrobenzene on the lowtemperature fungus pathogens in winter turnip rape. Pub. Finnish Sta. Agric. Res. Board 148: 62-67.

(6) Jamalainen, E. A. 1956. Overwintering of plants in Finland with respect to damage caused by low-temperature pathogens. Ibid. 148: 5-30.

(7) _— 1958. Peltokasvien huonon talvehtimisen syistä ja talvituhosienien aiheuttamien vahinkojen torjuntatoimenpiteistä. Summary: On reasons for poor overwintering of field crops and control measures against damage caused by low-temperature parasitic fungi. Maat. ja koetoim. 12: 44-63.

(8) KоккоNen, P. 1927. Uber das Verhältnis der Winterfestigkeit des Roggens zur Dehnbarkeit und Dehnungsfestigkeit seiner Wurzeln. Acta forest. fenn. 33, 3.

(9) Maler, F. 1950. Über den Einfluss von mechanischen Verletzungen auf Wasseraufnahme und Keimfähigkeitswerte der Getreidefrüchte. Saatgut - Wirtschaft 10: 228 -231; 11: $251-255$.

(10) Pohjakallio, Onni \& Salonen, Arvi 1958. Kymmenen vuotta kenttäkoetoimintaa Muddusniemen koetilalla Lapissa. Summary: Ten years of experiments on Muddusniemi experimental farm in Lapland. Maatal. ja koetoim. 12: 42-54.

(11) VAlle, O. 1954. Kokemuksia syysrypsin viljelytoiminnasta Suomessa. Maatalous 47: 197 -200. 


\title{
MÖHÖJUURITAUDIN JA TALVIPAKKASEN VAIKUTUKSESTA SYYSRYPSIN TALVEHTIMISEEN
}

\author{
Onni Pohjakallio, Anna Marja Halkilahti ja Simo Antila
}

\section{Yliopiston kasvipatologian laitos, Helsinki}

Möhöjuuritauti heikensi huomattavasti syysrypsin talvenkestävyyttä (taulukko 1).

Peltolohkolla, jolla möhöjuurta, talvituhosieniä, pintajäätä ja vesivaurioita ei esiintynyt, syysrypsi talvehti runsaslumisella alueella parhaiten; lumettomilla alueilla suuri osa kasveista kuoli ilmeisesti pakkasen vaikutuksesta (taulukko 2). Monien keväällä toipuneiden kasvien pääjuuren alaosa oli $2-3 \mathrm{~cm}$ kasvin tyvestä lähtien tuhoutunut (kuva 2). Tällaista vioittumista ilmeni sitä enemmän mitä huonommin syysrypsikasvusto oli talvehtinut (taulukko 2). Siten näytti siltä, että juuren kuoleminen oli johtunut paleltumisesta.

Termostaattihuoneessa $\left(-15^{\circ} \mathrm{C}\right)$ syysrypsin juuristo paleltui ratkaisevasti nopeammin kuin kasvin tyvi ja lehtiruusukkeen sisimmät lehdet (taulukot $3-5$; kuvat 3 ja 4). 